\title{
安澄の『中論疏記』に見られる聡法師 『成実論章』に関する考察
}

崔 恩 英

\section{1.はじめに}

魏晋南北朝時代の『成実論』と成実論師の見解を知るためによく参照されてき たのが，三論宗の文献，特に吉蔵（549-623）の注釈書であり，その中の一つに『中 観論疏』がある、ところが，『中観論疏』に抢ける引用は，取意であるためであろ うか，原典の中に該当する文言を見出せない場合も少なからずある．このような 理由から，南北朝時代の成実学を理解するためには，より信頼性のある文献を検 討すべきだとの意見が近年出されている，例えば船山徹は，日本の三論学僧であ る安澄（763-814）の『中論疏記』に引用された諸文献の方が，正確度がより高い と指摘する ${ }^{1)}$. 近年，蔵外写本の研究が進み，これまで直接的な資料に乏しかっ た成実論師の思想に対する研究も新たな段階に入っているが2)，一方でこれまで 注意されてきた三論文献における冕文の検討も未だ十分とはいえない面がある. そこで本稿では，『中論疏記』にしばしば言及される「聡法師」という人物に着目 し，関連する記述を考察することとしたい。

\section{2.「聡法師」について}

安澄が『中論疏記』において成実論師として最も多く引用するのは，開善寺智 蔵（458-522）である．智蔵は周知のごとく，梁の三大法師の一人として知られる 人物であり，その行状も『続高僧伝』巻五の智蔵伝に詳しい. 一方, 本稿で着目 する聡法師については，その人物像は殆ど知られていない．

管見の限り，聡法師の『成実論』の注釈と思われる『成実論章』(後述のとおり 『成論章』『聡章』などの異称はあるが，以下『成実論章」とする）が引用されるのは， 『中論疏記』と同じく日本撰述の吉蔵『三論玄義』に対する注釈書である澄禪 (12271307）の『三論玄義検幽集』だけであり ${ }^{3)}$ ，極めて参照が限られていることがまず 
特徵である. かつて伊藤隆寿は，この聡法師が北魏の成実論師である道記の弟子， 慧聡であることを示唆した ${ }^{4)}$ ，ただし，慧聡については『続高僧伝』巻六「法貞 伝」(461-521）に付伝されるものの5)，著述や生没年そして思想的な特徵に関する 明確な記述はない. よって, 逸文の撰者であるかを直ちに決することは困難である.

また，『中論疏記』においても，「聡（法師）『(文献名)』」「疏云」などと引用さ れるだけであり，更に中国や日本の目録にも関連しそうな記録は見られないため， 聡法師に関する情報は皆無に等しい状況である. あるいは中国撰述ではない可能 性もあろうが，伊藤隆寿や船山徹などの先行研究には，その点に関して言及する ところはない.

しかしながら，『中論疏記』には吉蔵が提示した『成実論』の説を聡法師の解釈 によって把握するところが見られるので ${ }^{6)}$ ，安澄は聡法師の見解を『成実論』を 解釈する重要な基準の一つとしていたことがわかる，したがって，聡法師は阿毘 最の教理を熟知した，成実師を代表する人物であった可能性もある7).

\section{3.『成実論章』における聡法師の逸文分析一一四諦と大乗四聖諦について一}

伊藤隆寿は，『中論疏記』に引用された聡法師の『成実論章』を 39 回と数えて いる ${ }^{8)}$. そのことを踏まえ，筆者が改めて逸文と思われるものを調査したところ， 以下のような結果となった。

まず，『成実論章』の場合，『成論章』『成実論章』『聡章』といった文献名を挙 げた逸文は重複する内容を含めて 13 箇所である。また，「成実論聡法師疏第三巻 法聚品」「聡法師疏第八」のように，文献名としてではなく「聡法師の疏」といっ た具合で巻数が示された文章も 2 箇所ある. 更に,「(聡法師) 解, ……云, ……疏 云」など, 文献名を明示しないものも重複を含めて 18 箇所が確認された，これら を合計すると，聡法師に関連する具体的な文章は，筆者の調査によれば 33 箇所と なる ${ }^{9)}$.

『中論疏記』に引用される聡法師の『成実論章』からと思われる 33 䇢所の文章 を分類すると，巻一から 8 箇所，巻二から 2 箇所，巻三から 1 箇所，巻四から 3 箇所, 巻八から 1 箇所であり, 残りは典拠となる巻数が明らかにはされていない. この中，巻一が多く参照されていることがまず注目されるが，その内容はほとん ど『成実論』の大義や四聖諦に関わる解釈である.

特に，その中には『成実論」を大乗とする観点と関連したものが含まれている ことが特徴である。三論教学においては，『成実論』を大乗とみなす立場に対し 
て, 徹底的に批判を加える.このような教学を背景として, 聡法師の説が参照さ れたと考えられるが，その点をここではより詳しく検討していきたい.

(1)言 “五者成実大乗義云”10) 等者. 所言 “成実大乗義” 者, 案聡法師章第一巻云, “説四諦 制立，有五重．一制立乃至五大小異．乃至第五大乗夫人経明四聖諦，明義広達而不別制 立. 是明界外变易生死. 故成無辺聖諦. 大経亦爾. 四諦本是正化声聞. 於大士是通行之 境故. 於大乗非始制立不明而已. 明其界内与小乗不異. 但其変易, 以無漏為因, 無明為 縁. 而亦不取前意” 准此章文, 釈成実論章疏之中, 有明大乗義之処. 今指其処. 故云成実 大乗義，不須異釈也.（T.65, pp. 111c28-112a9）

まず，(1)で聡法師は，四聖諦は声聞を教化する法ではあるが，菩薩にも通用す るため，大乗で別途の制立をしないとし，ただ，界外変易生死の無辺聖諦を明か す点が，小乗と界内分段生死との違いであると解釈している。この際，『勝鬟経』 と『涅槃経』を経証として挙げており，安澄は「『成実論』を解釈する注釈書の中 では，大乗の義を明かす部分もある．今のこのところを指す。」と説明する.

(2)言 “所以大小乗” 等者．案，聡法師成論意 ${ }^{11)}$ 初巻云 “生滅流動，是為三聚法体．有此為 故, 詺之有為. 三無為. 無此為故名無為. 勝琿経言 ‘三諦入有為, 唯一滅諦, 是無為也’ 大乗所明”准之可悉. (T.65, p. 229c3-7)

(2)においても，『勝珼経』を引用し，四諦のうち滅諦だけが無為であり，これ こそが，大乗が明らかにしょうとする内容であることを表している.

『勝覺経』は作・無作の二聖諦を説く、これは声聞だけを教化する法である四聖 諦を如来にまで拡大する内容である。『涅槃経』「四諦品」にもまた，単に生死流 転する苦集滅道とは異なり，聖諦である苦集滅道は如来と法の深甚常住不変を知 り，その上で煩悩を修めて消滅させることであるという説示がある ${ }^{12)}$. 声聞四果 を証得するための四諦説を超えた，大乗の四諦説の形態が，『勝㙞経』と『涅槃 経』に見られるのである。

現存する『成実論』は全体を発聚と四諦聚に二分し，発聚の中に「四諦品」を 含んでいる．しかし，「四諦品」の記述は，煩悩と業を修めて四諦を極めれば阿羅 漢となるという一般的な苦集滅道の四諦の説明である.『成実諭』には，大乗経典 で説明するような四聖諦の記述は全く見当たらない．したがって，聡法師の見解 からは，当時の成実論師たちが『成実論』の内容が大乗にまで通じていることを 説明するために，『勝䈜経』と『涅槃経』の内容を取りこんでいたことがわかるの である。

『成実論』には無明を説明する際に『師子吼経』を引用していることから ${ }^{13)}$, 
撰者の訶梨跋摩は『勝謷経』のことを知っていたと考えられる.しかし，『成実 論』「四諦品」には『勝鮟経』の八聖諦や大乗四諦説の内容が反映されていない. このような状況で，『成実論章』において『成実論』の大乗義を明らかにしなが

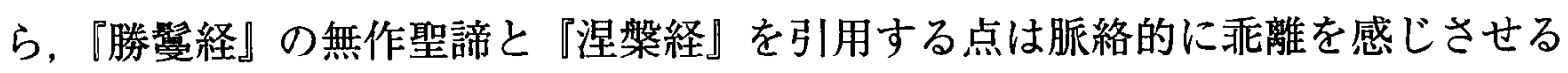
ものと言えよう。

(3)言 “又成論者云” 等者. 案, 聡 14) 章初巻云, “第一大意者, 仏説四諦理, 是法輪之始, 化声聞法. 凡有二意, 一通引要門, 二入空勝詮. 此有近遠. 遠者, 為除三惑, 先調其心. 近者, 令四諦平等, 入第一義空也. 言 ‘四諦平等” 者, 即有両義. 一捉苦諦入空. 謂以無 常等柝法, 作不有不無観. 則入第一義空 $\square \square$ 一時平等. 二者相待入空. 謂苦 $\square \square \square$ 滅. 苦既不実，滅則為 $\square \square \square \square \square \square \square \square \square \square$. 如此相待観門，入第一義空” 准之可悉.（T.65, p. 229c7-16)

(3) は，仏が初転法輪において声聞を教化するため，四諦を説いた二つの意図を 挙げているが, ここで着目したいのは, 四諦空を悟る二つの方法の中の一つとし て四諦平等にして第一義空に入らせるという部分の説明である.『中論疏記』は一 部欠字があり，内容がはっきりとしないが，これについては幸い，『三論玄義検幽 集』に同じ部分からの引用と思われる箇所があるため，不明瞭な部分を補うこと ができる. (4)の下線部は, (3)において久字となっていた部分である.

(4)一従苦諦入空. 謂以無常等拆法作不有不無観. 則入第一義空四諦一時平等. 二者相待 入空. 謂苦不自生由集而有，既無自性苦則非苦，苦既非真集則不有．苦除為滅．苦既不 実滅，則為空. 由滅空故道亦不真. 如此相待観門入第一義空.（T.70, pp. 421c27-422a3）

さて，これらの内容を総合して見てゆくと，四諦平等の入空には更に二つの方 法があるという。一つは苦を見ながら同時に集・滅・道を全体として見て第一義 空に入り，四諦が一気に平等となる従苦諦入空である.もう一つは相待入空であ る。すなわち，苦が集に基づくから自性がない，苦が真でないなら集は有でない といったように，相対して観察していくように空を理解する方法のようである.

このような聡法師の理解は，『成実論』巻三の次第品第二十六に説かれる次第見 と，次いで一時品第二十七に説かれる一時見に基づくものと思われるが，管見の 限り，他の文献には見られない独自の説のようである.

\section{4. おわりに}

以上に見たように，聡法師は四諦説が声聞と菩薩に共に通じる法であるから別 立せず，大乗にも四諦説があると説明している。しかし，そこで意図される大乗 
経の四諦説は『成実論』そのものには説示されるものでないことは看過されてい る、聡法師の見解を引用した文句をみると，当時の成実論師たちは『成実論』が 小乗の論書ではなく，大乗の説をも含んでいる経典として解釈しょうとしたこと がわかる．このような矛盾から，後に『成実論』を小乗であるとした三論教学に おける評価は，ある程度妥当であったことが理解されよう。

本稿では，安澄の『中論疏記』に散見される聡法師の逸文のうち四諦に関する 内容の考察にとどまったが，その他にも，空や業に関する解釈など，重要な論点 が少なくない。これらの検討については, 今後の課題としたい.

1）船山徹「梁の開善寺智蔵『成実論大義記』と南朝教理学」平成 15 年度〜平成 18 年度 科学研究費補助金基盤研究（B）研究成果報告書（1）『江南道教の研究』 2007.

2）池田将則「国立台湾図書館所蔵敦煌文献成実論義記巻中（台北 131）について (一)」 『浄土学研究』(韓国浄土学会) 21,2014では, 8 本の『成実論』の注釈書と思われる断 簡写本を挙げている.

3）中国で撰述された文献に見える「聡師（または聡法師）」は唐代の律師法聡を指すた め,ここでは考察の対象としない.

4）伊藤隆寿「安澄の引用せる諸註釈書の研究」『駒澤大学仏教学部論集』8, 1978, p. 137.

5）『続高僧伝』（T.50, p. 474b4-c4）.

6）聡法師云，第三解脱，何故空虚空者，以四大囲空成衆生，因四大明虚空，成衆生, 既四大空故所因虚空，自然故空虚空. 准此疏文. 今云. 成実者, 学成実論之師. 即聡 法師是也.（T.65, p. 150a4-8）.

7）聡法師疏釈云, 初問意数人義眼鼻井門等, 虚空是有為虚空是色法故. 問虚空色入性, 云何縁此過色相, 数人何故眼鼻井門等虚空為有為法者. 彼意. 無為虚空者. 無有分際. 遍一切処井門等虚空. 故能過色相. 今略引二番問答也. 前毘曇所説二種虚空. 准聡疏 意. 可悉. (T.65, p. 152a10-17).

8）伊藤前揭論文，p. 121. また，これに先行して福原隆善「吉蔵『中論疏』と安澄『中 論疏記』一特に成実学者との関連性を中心に一—」『印度学仏教学研究』23(2), 1975, p. 852 は 32 箇所とし, 聡法師の疏が「安澄の手元にあったような引き方である」だと する他，『成実論』との対応から 15〜20巻くらいの文献であったと推測する.

9）『中観疏記」の構成と合わせて大正蔵（SAT）で検索した時の頻出数に基づく．ただ 「准聡疏意, 可悉」とあって引用文がないものは含めていない.

10）『中観論疏』「五者成実大乗義云. 従無明識窟流来入三界, 初起一念善因為来, 反原 而去.」（T.42, p. 54a15-17）を指す.

11）「意」は甲本では「章」に作る.

12）『大般涅槃経』（T.12, p. 647a27-c20).

13）『成実諭』(T.32, p. 313b9-15).

14）「聡」は甲本では「法師成論」を加える。 
（40）安澄の『中論疏記』に見られる聡法師『成実論章』に関する考察（崔）

〈参考文献〉

池田将則 2014 「国立台湾図書館所蔵敦煌文献成実論義記巻中（台北 131）について (一)」

『浄土学研究』（韓国浄土学会）21:273-315.

伊藤隆寿 1978 「安澄の引用せる諸註釈書の研究」『駒澤大学仏教学部論集』8: 115-146.

福原隆善 1975 「吉蔵『中論疏』と安澄『中論疏記』一一特に成実学者との関連性を中心 に一」『印度学仏教学研究』23(2): 849-852.

船山徹 2007 「梁の開善寺智蔵『成実論大義記』と南朝教理学」平成 15 年度〜平成 18 年

度科学研究費補助金基盤研究（B）研究成果報告書（1）『江南道教の研究』，111-135.

（2007 年韓国政府教育科学技術部の財源による韓国研究財団の支援 NRF-361-2007-1AM0046による研究成果の一部)

〈キーワード〉 聡法師, 『成実論章』, 『成実論』, 安澄, 『中論疏記』, 四諦

(金剛大学校仏教文化研究所 HK 教授, 哲学博士)

\section{新刊紹介}

吉水 岳彦 著

\section{霊芝元照の研究 宋代律僧の浄土教}

A5 版 $\cdot 432$ 頁・本体価格 12,000 円 法蔵館・2015 年 11 月 